\section{PEMBERDAYAAN IBU PKK DESA BLEBERAN MELALUI PELATIHAN KEWIRAUSAHAAN DALAM UPAYA MENDUKUNG DESA WISATA BLEBERAN}

Eko Hari Parmadi"*, Yohanes Heri Widodo ${ }^{2}$

1)Informatika, Universitas Sanata Dharma

2)Bimbingan Konseling, Universitas Sanata Dharma

\begin{abstract}
Abstrak
Desa Bleberan merupakan salah satu tujuan wisata yag banyak diminati oleh para wisatawan. Objek wisata yang menjadi daya tarik adalah air terjun Sri Gethuk. Salah satu yang menjadi permasalahan adalah sedikitnya warung atau usaha yang berada di sekitar objek wisata. Pengabdian masyarakat ini bertujuan untuk mengevaluasi keberhasilan program pemberdayaan melalui pelatihan kewirausahaan. pendampingan serta praktek langsung berjualan atau memasarkan produk di daerah objek wisata Sri Gethuk. Program pengabdian ini melibatkan ibu-ibu PKK Desa Bleberan yang terlibat berjumlah 16 orang. Program pemberdayaan dilakukan lewat beberapa tahap. Tahap pertama adalah peningkatan motivasi berwirausaha dan tahap kedua lewat pelatihan analisis usaha pembuatan makanan ringan dari bahan baku yang ditemukan di sekitar tempat tinggal ibu-ibu PKK. Hasil kegiatan ini menunjukkan bahwa sesudah menjalani pelatihan sebagian besar peserta $(62,5 \%)$ memiliki motivasi berwirausaha yang tinggi. Motivasi berwirausaha diukur dengan skala motivasi berwirausaha. Selain itu, semua peserta juga memandang bahwa kegiatan ini bermanfaat karena dapat menambah pengetahuan dan pengalaman dalam berwirausaha. Hal ini membuat peserta pelatihan merasa senang dan lebih percaya diri untuk merencanakan dan menjalani suatu program kewirausahaan di tahap berikutnya. Tahap ketiga adalah mempraktekkan langsung rencana usaha yang telah dibuat dengan cara membuat produk kreatif dan tahap keempat adalah pelatihan membuat kemasan serta pemasaran produk di tempat wisata Air Terjun Sri Gethuk.
\end{abstract}

Kata Kunci: Kewirausahaan; Pelatihan; Pemberdayaan

\section{Article history \\ Received : 03-12-2020 \\ Revised : 05-03-2021 \\ Accepted : 06-04-2021}

\section{*Corresponding author \\ Eko Hari Parmadi \\ Email: hari@usd.ac.id}

\begin{abstract}
Bleberan Village is one of the most popular tourist destinations for tourists. The tourist attraction that is the main attraction is the Sri Gethuk waterfall. One of the problems is the lack of stalls or businesses around the tourist attraction. This community service aims to evaluate the empowerment program's success through entrepreneurship training, mentoring, and direct practice of selling or marketing products in the Sri Gethuk tourist area. This service program involved 16 PKK women in Bleberan Village. The empowerment program is carried out in several stages. The first stage is to increase entrepreneurial motivation. The second stage is through business analysis training to make snacks from raw materials found in PKK mothers' neighborhoods. This activity indicated that most of the participants (62.5\%) had high entrepreneurial motivation after undergoing training. The entrepreneurial motivation scale measures entrepreneurial motivation. In addition, all participants also saw that this activity was helpful because it could increase knowledge and experience in entrepreneurship. This makes trainees feel happy and confident about planning and undergoing an entrepreneurship program later. The third stage is to directly practice the business plan that has been made by making creative products, and the fourth stage is training in packaging and product marketing at the Sri Gethuk Waterfall tourist spot.
\end{abstract}

Keywords: Entrepreneurship; Training; Empowerment

\section{PENDAHULUAN}

Tercapainya masyarakat yang sejahtera dalam berbagai bidang merupakan tujuan dalam pembangunan masyarakat. Tujuan ini perlu dicapai lewat berbagai macam cara dan mendorong peran aktif dari berbagai komponen masyarakat. Hal ini ternyata bukanlah hal yang mudah khususnya dalam masyarakat yang masih memiliki masalah yakni kesetaraan peran di antara warganya. Dalam masyarakat semacam ini, tentu dimarjinalkan dalam 
peran kehidupannya sehari-hari. Marjinalisasi terjadi misalnya dalam bidang politik, agama, dan ekonomi. Salah satu kelompok dalam masyarakat yang sering mendapat perlakuan marginal semacam ini adalah kaum perempuan.

Meskipun memiliki peran penting dalam beberapa kelompok masyarakat, peran wanita dipandang belum bisa disejajarkan dengan laki-laki. Wanita biasanya dianggap tidak memiliki peran yang sama pentingnya dengan laki-laki. Dalam banyak kasus yang terjadi pada masyarakat di Indonesia, bahkan ketika wanita memiliki peran yang lebih besar dari laki-laki, mereka tidak akan diizinkan mengambil peran yang setara. Ketidaksetaraan ini muncul di berbagai bidang misalnya pengambilan keputusan, pembagian kerja, sistem kepemilikan, dan sistem pembagian sumber daya (Susanto, 2015). Gerakan kesetaraan gender sebenarnya sudah dimulai jauh-jauh hari oleh R.A. Kartini, tetapi masih banyak ditentang hingga hari ini tidak hanya oleh masyarakat biasa bahkan juga oleh sebagian kaum akademisi. Gerakan kesetaraan gender ini banyak dituduh sebagai langkah mundur dari nilai-nilai budaya timur akibat pengaruh budaya barat (Intan, 2014)

Pengabaian terhadap peran penting wanita ini mengundang masalah tersendiri. Pertama tentu pada masalah pada wanita itu sendiri. Ketika wanita dimarjinalkan, akses mereka terhadap berbagai sumber akan dibatasi. Hal ini akan menghambat berkembangnya potensi pada kelompok ini. Masalah berikutnya adalah ketidakseimbangan perkembangan suatu masyarakat akibat lebih dominannya satu bagian masyarakat yang mengakibatkan termarginalkannya kelompok masyarakat yang lainnya ketidakseimbangan.

Berdasarkan fenomena ini, sangatlah penting untuk melakukan pemberdayaan wanita demi tercapainya kesetaraan gender dalam masyarakat yang pada akhirnya akan mendorong terjadinya kesejahteraan suatu masyarakat dalam segala aspek. Salah satu langkah penting adalah mempromosikan kesetaraan gender dalam bidang pendidikan menghilangkan perbedaan gender dalam pemenuhan akses pendidikan pada pria dan wanita (Mursidah, 2014)

Salah satu aspek yang bisa menjadi perhatian dalam pemberdayaan wanita terkait dengan kesetaraan gender adalah pemberdayaan ekonomi. Pengabdian masyarakat ini bertujuan menilai pelaksanaan program pemberdayaan ekonomi lewat pelatihan kewirausahaan pada ibu-ibu PKK di Desa Bleberan. Desa Bleberan adalah sebuah wilayah yang terletak di Kabupaten Gunung Kidul. Desa ini, sejak lama telah mencanangkan dirinya sebagai Desa wisata. Tempat wisata yang menjadi andalannya adalah air terjun Sri Gethuk. Tempat wisata ini cukup ramai dikunjungi wisatawan khususnya di hari-hari libur. Namun demikian, keberadaan air terjun Sri Gethuk tampaknya belum dapat secara optimal mendongkrak perekonomian Desa Bleberan. Salah satu yang diduga menjadi penyebabnya adalah masih terbatasnya peran wanita khususnya kaum ibu sebagai bagian yang penting dalam suatu kelompok masyarakat. Oleh karenanya, perlu dirancang sebuah program yang dapat memberdayakan kaum wanita khususnya ibuibu dalam hal ini adalah mereka yang tergabung dalam kelompok ibu-ibu PKK Desa Bleberan.

Pemberdayaan berasal dari empowerment yang bermakna pemberian daya atau penguatan (Strengthening) kepada masyarakat (Theresia et al., 2014). Pemberdayaan mengacu pada bagaimana individu, kelompok, atau komunitas mengendalikan hidup mereka sendiri untuk masa depan sesuai dengan pilihan mereka sendiri (Adams et al., 2017). Pemberdayaan bertujuan membantu klien memperoleh daya untuk mengambil keputusan dan menentukan tindakan yang akan ia lakukan yang terkait dengan diri mereka, termasuk mengurangi efek hambatan pribadi dan sosial dalam melakukan tindakan (Rifa'i, 2013). Selain itu, pemberdayaan juga bertujuan untuk merumuskan kembali adanya pilihan atau derajat kebebasan yang dimiliki individu sebagai agen yang memiliki kendali atas lingkungannya serta dapat merasakan dan menyadari pengaruh kemampuan kendali yang dimilikinya tersebut (Salge et al., 2014). Di sisi lain, pemberdayaan yang dilakukan pada seseorang atau sekelompok orang akan mampu mendorongnya memiliki keyakinan diri untuk dapat meraih suatu capaian tertentu yang dicita-citakannya sejak semula (self efficacy) (Kim et al., 2011).

Salah satu implementasi pemberdayaan adalah melalui kewirausahaan yang mencakup konsep yang bersifat multidimensional (Gedeon, 2010). Kewirausahaan sendiri perkembangannya tidak lepas dari adanya faktor kesempatan. Kesempatan yang datang di waktu yang tepat akan menjadi titik awal yang mendorong suatu kewirausahaan. Kewirausahaan juga berhubungan dengan beberapa aspek kepribadian dalam diri seseorang yakni efikasi diri, kebutuhan untuk berprestasi, dan orientasi berwirausaha (Frese \& Gielnik, 2014).

\section{METODE PELAKSANAAN}

Pengabdian masyarakat ini dilaksanakan secara terintegrasi dengan pelaksanaan Kuliah Kerja Nyata (KKN). Tahap pertama pelaksanaan pengabdian diisi dengan pelatihan pemberdayaan ibu-ibu PKK Desa Bleberan. Kegiatan pelatihan ini diharapkan dapat meningkatkan peran wanita dapat meningkatkan perekonomian mereka melalui kewirausahaan (Gambar 1). 


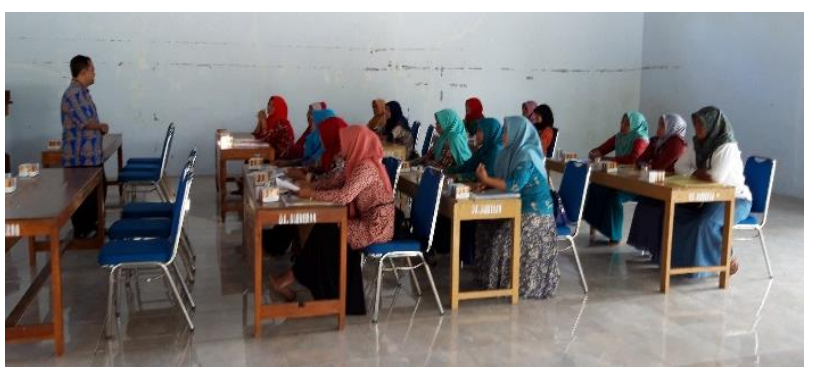

Gambar 1. Pelatihan motivasi berwirausaha

Tahap kedua berupa pelatihan untuk para ibu PKK dalam mempersiapkan diri menjadi wirausahawan. Para ibu dibagi manjadi 5 kelompok usaha dan setiap kelompok wajib merancang dan menghasilkan usaha kreatif. Tiap kelompok dibekali dengan analisis usaha produk makanan ringan, strategi penentuan harga, penghitungan biaya produksi.

Tahap berikutnya, mahasiswa KKN melakukan pendampingan dalam pembuatan makanan ringan yang akan dijadikan usaha. Makanan ringan yang diproduksi oleh Ibu-lbu PKK antara lain Donat TELO, Abon Pepaya, Ceriping Balado, Nugget Lele serta Popcorn. Mahasiswa juga membantu tiap kelompok dalam hal kemasan serta label. Bagian akhir program ini adalah pelaksanaan Ekspo kelompok usaha di lingkungan Air Terjun Sri Gethuk (Gambar 2).

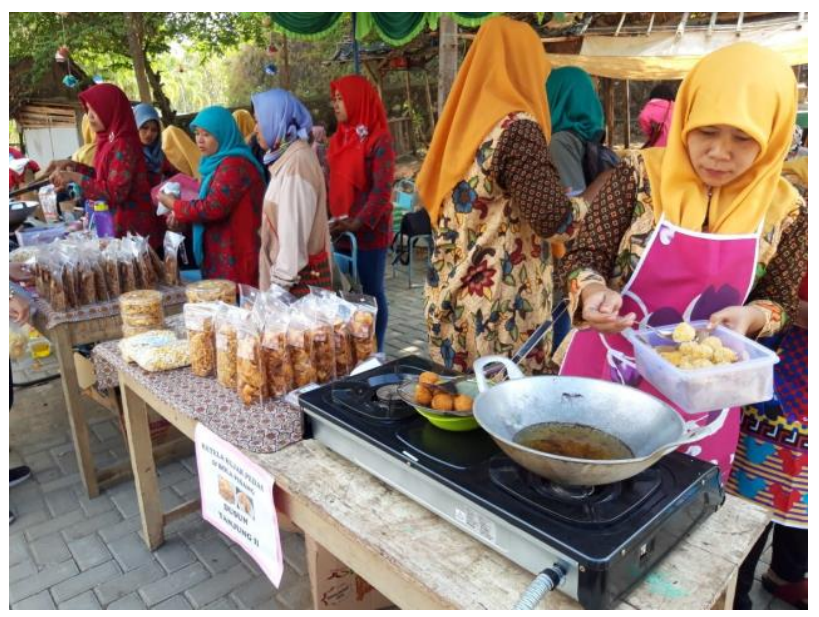

Gambar 2. Penjualan produk di area wisata

\section{PEMBAHASAN}

\section{Program Pemberdayaan}

Pemberdayaan Ibu-lbu PKK dapat dilakukan dengan beberapa cara. (Hamid et al., 2018) melakukan pemberdayaan ibu-ibu PKK melalui social preneur sebagai upaya dalam meningkatkan kesejahteraan masyarakat Desa Pettalandung Kecamatan Malangke Kabupaten LuwU Utara. Kegiatan pemberdayaan yang dilakukan berupa memberikan beberapa keterampilan usaha serta memanfaatkan internet, salah satunya pembuatan blog sebagai media promosi. Pemberdayaan lbuIbu PKK juga dapat dilakukan melalui pelatihan (Hunaepi et al., 2017) dan pendampingan produksi (Susanti \& Susilowati, 2016).

Program pemberdayaan pada kegiatan pengabdian ini dilakukan pada 16 orang ibu-ibu PKK Desa Bleberan pada hari Minggu tanggal 14 Juli 2019 bertempat di Balai Desa Bleberan. Program dibuat untuk memanfaatkan hasil pekarangan rumah seperti papaya, jagung, ketela, kacang tanah dan sebagainya. Program pemanfaatan pekarangan rumah dengan teknik budidaya tanaman sayuran secara vertikultur mampu mengoptimalkan fungsi lahan (Harimurti, 2020).

Program pemberdayaan ini mempunyai tiga program yaitu pemberian motivasi berwirausaha, pelatihan analisis usaha produk makanan ringan dan pembuatan produk dan pemasaran. Program pemberian motivasi ibu-ibu PKK di Desa Bleberan dari sesi psikologi betujuan mendorongan dari dalam diri untuk memiliki cara berpikir dan bertindak sebagai seorang wirausahawan. Sesi ini berlangsung sekitar 1,5 jam. Kegiatan pelatihan analisis usaha, para peserta dibagi menjadi kelompok-kelompok berdasarkan wilayah tempat tinggalnya. Usaha yang diusulkan untuk dikembangkan adalah usaha pembuatan produk makanan ringan. Makanan ringan dibuat dengan bahan dasar yang mudah didapatkan di wilayah Desa Bleberan. Selanjutnya, peserta dilatih melakukan analisis usaha sehingga bisa memperkirakan hasil yang diperoleh termasuk juga mengantisipasi adanya kerugian dalam usaha. Sesudah melakukan pelatihan, peserta minta untuk mulai melakukan pembuatan produk secara berkelompok di wilayah masing-masing. Pada akhirnya, produk yang sudah selesai dibuat dipasarkan di area wisata Sri Gethuk pada hari minggu (Gambar 3).

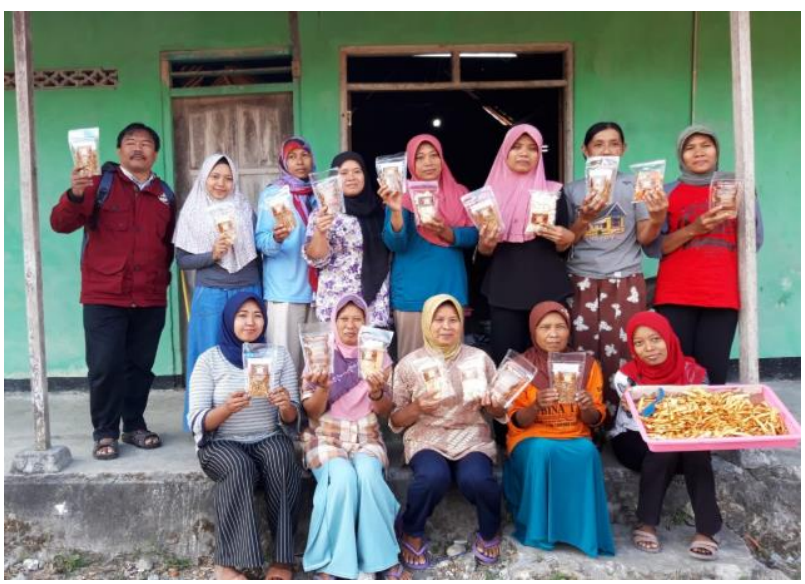

Gambar 3. Produk hasil produksi ibu-ibu PKK 


\section{Pengukuran motivasi berwirausaha}

Pengukuran terhadap motivasi berwirausaha terhadap 16 orang ibu-ibu PKK. Pengukuran menggunakan alat ukur motivasi berwirausaha yang didasarkan pada penelitian Shane et al. (2003) (Tabel 1). Alat ukur ini memiliki Reliabilitas yang cukup baik yakni 0,74. Hasil pengukuran motivasi berwirausaha menunjukkan peserta yang mempunyai motivasi yang tinggi sebesar 62,5\% (Tabel 2).

Tabel 1. Kategorisasi "Entrepreneurial motivation. Human Resource Management Review"

\begin{tabular}{ll}
\hline \multicolumn{1}{c}{ Kategori } & \multicolumn{1}{c}{ Rumus } \\
\hline Sangat tinggi & $M+1,5 S D<X$ \\
Tinggi & $M+0,5 S D<X<M+1,5 S D$ \\
Sedang & $M-0,5 S D<X<M+0,5 S D$ \\
Sangat Rendah & $X<M-1,5 S D$ \\
Rendah & $M-1,5 S D<X<M-0,5 S D$ \\
\hline
\end{tabular}

Tabel 2. Hasil pengukuran motivasi berwirausaha

\begin{tabular}{lr}
\hline \multicolumn{1}{c}{ Kategori } & Jumlah \\
\hline Sangat tinggi & $0 \%$ \\
Tinggi & $62,5 \%$ \\
Sedang & $12,5 \%$ \\
Rendah & $18,75 \%$ \\
Sangat Rendah & $6,25 \%$ \\
\hline & $100 \%$ \\
\hline
\end{tabular}

\section{Analisis kualitatif}

Perasaan yang muncul sesudah mengikuti pelatihan yang paling banyak adalah perasaan senang (30\%).

\footnotetext{
"senang dapat pengalaman baru dan semoga saya dapat melakukannya".

"senang dan menambah ilmu pengetahuan tentang usaha".
}

Setelah perasaan senang, hal yang dirasakan paling banyak oleh peserta pelatihan diurutan kedua adalah munculnya perasaan lebih percaya diri $(25 \%)$ :

"Lebih percaya diri dan yakin bahwa semua orang mempunyai kelebihan"

"Yakin kalau bisa mendapatkan penghasilan"

"Yakin bahwa saya bisa membuka usaha"

Pada pertanyaan apakah pelatihan ini bermanfaat, seluruh peserta mengungkapkan bahwa mereka merasa pelatihan tersebut bermanfaat (100\%). Selanjutnya, sebanyak $50 \%$ respon menunjukkan bahwa manfaat yang diperoleh adalah menambah pengetahuan

"lya. menambah wawasan dan pengetahuan tentang kewirausahaan"

\begin{abstract}
"Bisa menambah wawasan berwirausaha dalam rumah tangga"

"Mendapatkan ilmu bagaimana cara memperoleh hasil yang membuat kita tidak merugi dan dapat menghitung BEP"

"Menambah wawasan dan cara berwirausaha yang lebih baik untuk menuju sukses"
\end{abstract}

Respon terbanyak terkait dengan pertanyaan manfaat pelatihan adalah menambah pengalaman. Hal ini muncul dalam $25 \%$ dari peserta

"Menambah pengalaman dalam bidang usaha"

"Mendapat pengalaman yang dapat diambil dan dipraktekkan di rumah"

"Menambah pengalaman menjadi wanita sukses dan mandiri tidak tergantung pada suami, saling mendukung dan membantu"

\section{KESIMPULAN}

Program pemberdayaan ibu-ibu PKK Desa Bleberan menunjukkan pengaruh yang positif. Hal ini bisa dilihat dari dua hal. Pertama, sebagian besar peserta yakni 62,5\%, menunjukkan motivasi berwirausaha yang tinggi setelah pelatihan. Hal kedua yang menunjukkan pengaruh positif dari program pelatihan pemberdayaan ibu-ibu PKK Desa Bleberan adalah berhasil diciptakannya secara kreatif produkproduk makanan ringan berdasarkan bahan baku yang ditemukan di Desa Bleberan. Produk tersebut laku untuk dipasarkan di area wisata setempat.

Kemampuan menghasilkan produk dan tingginya motivasi menunjukkan adanya pengaruh positif pelatihan kewirausahaan yang telah dilakukan. Kedua hal ini berhubungan dengan cukup erat. Motivasi berperan untuk memulai dan selanjutnya mempertahankan proses kewirausahaan yang dijalankan individu. Peran mempertahankan ini akan tampak jelas saat munculnya berbagai kesulitan atau kegagalan dalam proses kewirausahaan yang dijalankan. Kegiatan pengabdian selanjutnya, direncanakan adanya proses pendampingan dalam memperoleh ijin PIRT, penguatan kelompok usaha secara organisasi maupun diversifikasi produk, serta pengembangan usaha lebih lanjut melalui pemasaran online dan pencatatan penjualan dan pengeluaran secara digital.

\section{UCAPAN TERIMA KASIH}

Kami ucapkan terima kasih kepada (1) Lembaga Penelitian dan Pengabdian Kepada Masyarakat yang telah memberikan dana hibah Pengabdian terintegrasi KKN, (2) lbu- ibu PKK Desa Bleberan yang telah menjadi mitra kegiatan KKN serta (3) para mahasiswa KKN yang dengan semangat dan kreatif mendampingi para ibu-ibu PKK Desa Bleberan dalam berwirausaha. 


\section{DAFTAR PUSTAKA}

Adams, R., Dominelli, L., \& Payne, M. (2017). Social Work: Themes, Issues and Critical Debates. Macmillan Education UK. https://books.google.co.id/books?id=SpIMDWAAQB AJ

Frese, M., \& Gielnik, M. M. (2014). The Psychology of Entrepreneurship. Annual Review of Organizational Psychology and Organizational Behavior, 1(1), 413438. https://doi.org/10.1146/annurev-orgpsych$031413-091326$

Gedeon, S. (2010). What is entrepreneurship. Entrepreneurial Practice Review, 1 (3), 16-35.

Hamid, R. S., Anwar, S. M., Rahmatia, R., \& Ikbal, M. (2018). Pemberdayaan Ibu-lbu Pkk Melalui Social Preneur Sebagai Upaya Dalam Meningkatkan Kesejahteraan Masyarakat Di Desa Pettalandung. Jurnal Dedikasi Masyarakat, 2(1), 23-29. https://doi.org/10.31850/jdm.v2i1.362

Harimurti, S. (2020). Pemanfaatan Pekarangan Rumah dengan Teknik Budidaya Tanaman Sayuran secara Vertikultur. Journal of Community Service, 2(1), 44-46. https://idm.or.id/JCS/index.php/JCS/article/view/33

Hunaepi, H., Samsuri, T., Firdaus, L., Mirawati, B., Ahmadi, A., \& Muhali, M. (2017). Pemberdayaan Ibu-lbu Pkk Melalui Pelatihan Produksi Deterjen Cair Di Desa Sukaraja Lombok Tengah. Lumbung Inovasi: Jurnal Pengabdian Kepada Masyarakat, 2(1), 65-67. http://journal-

center.litpam.com/index.php/linov/article/view/416

Intan, S. (2014). Kedudukan Perempuan Dalam Domestik Dan Publik Perspektif Jender (Suatu Analisis Berdasarkan Normatifisme Islam). Jurnal Politik Profetik, 2(1), 19-20. http://journal.uinalauddin.ac.id/index.php/jpp/article/view/957

Kim, B. (Peter), Lee, G., Murrmann, S. K., \& George, T. R. (2011). Motivational Effects of Empowerment on Employees' Organizational Commitment: A
Mediating Role of Management Trustworthiness. Cornell Hospitality Quarterly, 53(1), 10-19. https://doi.org/10.1177/1938965511426561

Mursidah, M. (2014). Pendidikan Berbasis Kesetaraan dan Keadilan Gender. Jurnal Muwâzâh, 5(2), 277-292. http://e-

journal.iainpekalongan.ac.id/index.php/Muwazah/a rticle/view/350

Rifa'i, B. (2013). Efektivitas Pemberdayaan Usaha Mikro Kecil dan Menengah (UMKM) Krupuk Ikan dalam Program Pengembangan Labsite Pemberdayaan Masyarakat Desa Kedung Rejo Kecamatan Jabon Kabupaten Sidoarjo. Sumber, 100(100), 2-59. http://www.journal.unair.ac.id/download-fullpapers16 Baktiar_KMP V1 N1 Jan-April 2013.pdf

Salge, C., Glackin, C., \& Polani, D. (2014). Empowerment-An Introduction. In Guided Self-Organization: Inception (pp. 67-114). Springer. https://doi.org/10.1007/978-3642-53734-9 4

Shane, S., Locke, E. A., \& Collins, C. J. (2003). Entrepreneurial motivation. Human Resource Management Review 13(2), 257-279 https://doi.org/https://doi.org/10.1016/S10534822(03)00017-2

Susanto, N. H. (2015). Tantangan mewujudkan kesetaraan gender dalam budaya patriarki. Muwazah: Jurnal Kajian Gender, 7(2), 120-130. http://repository.iainpekalongan.ac.id/129/

Susanti, E. , \& Susilowati, E. (2016). Pemberdayaan ibu-ibu PKK melalui pelatihan dan pendampingan produksi sabun dan deterjen. SEMAR (Jurnal IImu Pengetahuan, Teknologi, Dan Seni Bagi Masyarakat), 4(2), 87-96. https://jurnal.uns.ac.id/jurnalsemar/article/view/4570

Theresia, A., Andini, K. S., \& Mardikanto, T. (2014). Pembangunan berbasis masyarakat: acuan bagi praktisi, akademisi, dan pemerhati pengembangan masyarakat. Penerbit Alfabeta. https://books.google.co.id/books?id=PzfJoAEACAAJ 